[Bull. Agr. Chem. Soc. Japan, Vol. 23, No. 5, p. 428 437, 1959]

\title{
Islanditoxin, a Toxic Metabolite produced by Penicillium islandicum Sopp
}

\author{
Part III. Structure of Islanditoxin
}

\author{
By Shingo Marumo* \\ Department of Agricultural Chemisiry, Faculty of Agriculture, University of Tokyo \\ Received January 13, 1959
}

\begin{abstract}
Islanditoxin is a novel peptide consisted of five amino acids, three of which have been known as normal components of proteins and the remaining two, $D-\beta$-phenyl- $\beta$-aminopropionic acid and $L$ dichloroproline have not been encountered previously in nature. The structure of islanditoxin is shown to be a cyclic polypeptide, represented by formula (VIII).
\end{abstract}

The isolation of islanditoxin, a toxic peptide, from a culture broth of Penicillium islandicum, which caused the islandia yellowsis rice, was described in the previous papers ${ }^{1,3}$, and the general characterization and acid hydrolysis of islanditoxin were also reported ${ }^{2,4}$. . In this paper the author wishes to report the correction of molecular formula, some physical properties and chemical structure of islanditoxin as well as the existence of two novel amino acids, $D-\beta$-phenyl$\beta$-aminopropionic acid and $\mathrm{L}$-dichloroproline. On the basis of degradation experiments the structure of islanditoxin is proposed as (VIII).

When islanditoxin was recrystallized from methanol, isladitoxin monomethanolate, m.p. $250 \sim 1^{\circ}$, was obtained in colourless needles having one mole of methanol as the solvent of crystallization. Using water as the solvent, one mole of water was taken and islanditoxin monohydrate, m.p. $254^{\circ}$, was formed. The solvent of crystallization, methanol and water, were combined strongly with islanditoxin, and were not lost by vacuum-drying at $100^{\circ}$ for three

* Present address: The lnstitute of Physical and Chemical Research, Komagome Bunkyo-ku, Tokyo.

1) S. Marumo and Y. Sumiki, J. Agr. Chem. Soc, Japam, 29, 305 (1955).

2) S. Marumo, K. Miyao and A. Miesuyama, ibid., 29, 913 (1955).

3) S. Marumo, This Bulletin, 19,258 (1955).

4) S. Marumo, K. Miyao and A. Matsuyama, ibid., 19, 262 (1955). days and so by drying at $146^{\circ}$ (using tetrachloroethane) for three days. To obtain free islanditoxin, it was needed to recrystallize the monomethanolate or monohydrate from boiling acetone. On cooling the solution free islanditoxin, m.p. $258^{\circ}$, deposited in an amorphous form. The solubility of free islanditoxin was different from that of the monomethanolate and almost insoluble in ordinary solvents except phenol and glacial acetic acid. The molecular formula, microanalyses and infrared spectra of them (as Nujol mull) are shown in Fig. 1.

It is noted that the different among their infrared spectra is observed in the ranges of $3500 \sim 3300$ and $1100 \sim 1000 \mathrm{~cm}^{-1}$. corresponding to $\mathrm{OH}$ regions. Free islanditoxin, when recrystallized from methanol or water, forms the monomethanolate or monohydrate and this conversion is reversible if proper solvents are used.

The paper chromatography was carried out in order to examine the homogeneity of islanditoxin. On paper chromatograms only one spot was detected, hence islanditoxin is considered to be chromatographically a pure substance.

On the complete acid hydrolysis of islanditoxin $^{4)}$ there were obtained three ninhydrin possitive substances, two of which were identified as serine and $\alpha$-aminobutyric acid respectively 
FIG. 1 .

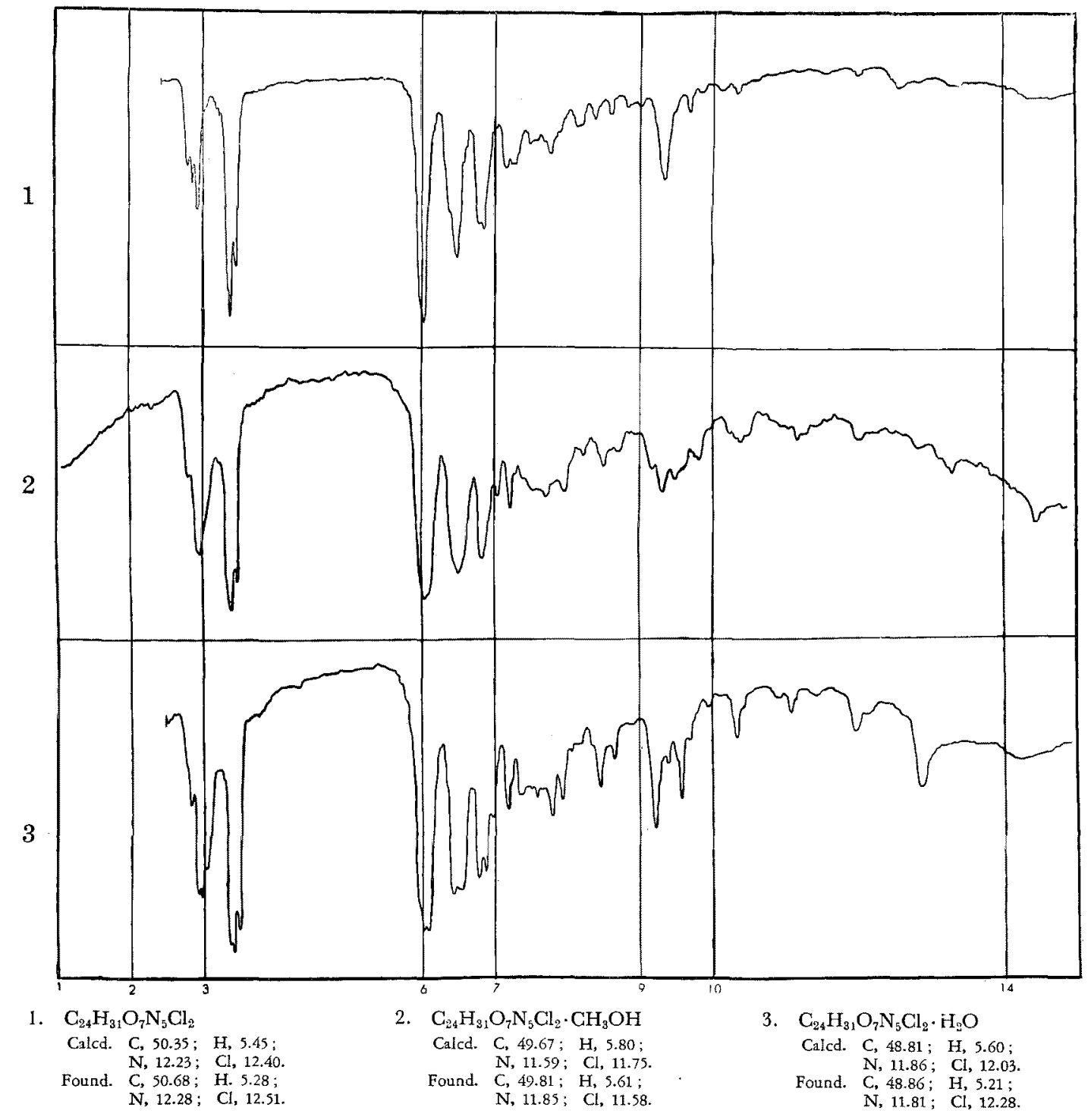

on the basis of their infrared spectra, $R_{F}$ values and melting points. The third amino acid, $\mathrm{C}_{9} \mathrm{H}_{11} \mathrm{NO}_{2}$, m.p. $230^{\circ}$ (decomp.), had infrared absorptions at $1600,1573,1510$, and $700 \mathrm{~cm}^{-1}$ indicating the presence of benzene ring. The ultraviolet absorption spectrum was found to be typical for the benzenoid, having maximum at $257 \mathrm{~m} \mu(\varepsilon, 220)$. On the paper chromatograms, $R_{F}$ value was a little higher than those of $\mathrm{DL}$ phenylalanine and it was considered that the compound could be an amino acid which had been unknown in nature. Quantitative deter- 


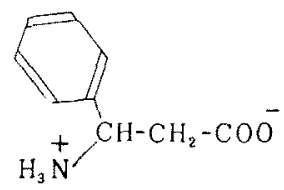

( I )<smiles>CC(N)(N)c1ccccc1</smiles>

(II)<smiles>[NH3+]c1cccc(CC(=O)[O-])c1</smiles>

(III) mination of serine and $\alpha$-aminobutyric acid was carried out by paper chromatography with acid hydrolyzate of islanditoxin. As the result, it was revealed that one mole of islanditoxin liberated two moles of serine and one mole of $\alpha$-aminobutyric acid.

The optical rotation measurement of serine obtained by acid hydrolysis gave $[\alpha]_{D}^{35^{\circ}}=+15.4^{\circ}$ (c, 3.5 in $1 \mathrm{~N}$-hydrochloric acid) showing that the amino acid was of L-series. $\alpha$-Aminobutyric acid was not oxidized by D-amino acid oxidase, hence the amino acid was found to be of $L^{-}$ series.

From the data obtained by acid hydrolysis, in islanditoxin there were two moles of $\mathrm{L}$-serines, one mole of $\mathrm{L}$ - $\alpha$-aminobutyric acid and one mole of $\mathrm{C}_{9} \mathrm{H}_{11} \mathrm{NO}_{2}$ and the sum of the molecular formulae of these four molecules makes $\mathrm{C}_{19} \mathrm{H}_{26} \mathrm{O}_{6} \mathrm{~N}_{4}$. Substructing it from the molecular formula of islanditoxin, there remains $\mathrm{C}_{5} \mathrm{H}_{5} \mathrm{NO}$ $\mathrm{Cl}_{2}$ as an unknown fragement which could not be obtained by acid hydrolysis but could be obtained by alkaline hydrolysis as described below.

Treatment of islanditoxin with saturated hot aqueous solution of barium hydroxide at $130^{\circ}$ for twenty hours, gave rise to two kinds of organic acids in addition to the above amino acids. These acids were separated respectively by submitting the alkaline hydrolyzate on the celullose column chromatography.

One of the organic acid, $\mathrm{C}_{5} \mathrm{H}_{5} \mathrm{NO}_{2}$, m.p. $180^{\circ}$ (decomp.), having ultraviolet absorption maximum at $261 \mathrm{~m} \mu\left(\varepsilon, 1.6 \times 10^{4}\right)$, was identified as $\alpha$-pyrrole carboxylic acid by usual methods comparing with an authentic sample, which was synthesized by Zugravescu's method ${ }^{5}$. It was

\footnotetext{
5) I. Zugravescu, Bull. Soc. Chim., (5), 5, 44 (1952).
}

presumed that this acid was originated from the unidentified fragement, $\mathrm{C}_{5} \mathrm{H}_{5} \mathrm{NOCl}_{2}$.

The second organic acid, $\mathrm{C}_{8} \mathrm{H}_{8} \mathrm{O}_{2}$, m.p. $130^{\circ}$, having ultraviolet absorption maximum at 272 $\mathrm{m} \mu\left(1.6 \times 10^{4}\right)$, was identified as cinnamic acid. As to the origin of cinnamic acid in the alkaline hydrolyzate of islanditoxin, the author considers it to be reasonable to assign the amino acid, $\mathrm{C}_{9} \mathrm{H}_{11} \mathrm{NO}_{2}$, which is deaminated by the action of $\mathrm{OH}$ ion to produce cinnamic acid. From the above result, it is possible to propose the structure of the amino acid, $\mathrm{C}_{9} \mathrm{H}_{11} \mathrm{NO}_{2}$, as being formula (I).

This amino acid had the following properties, a) from the infrared absorption at $3100 \mathrm{~cm}^{-1}$ $\left(-\mathrm{NH}^{+}\right)$and $1570 \mathrm{~cm}^{-1}\left(-\mathrm{COO}^{-}\right)$and the behaviors on filterpaper electrophoresis this was a neutral amino acid of zwitter ion type. b) the intensity of ninhydrin colouration was weaker than those of normal $\alpha$-amino acids and the developement of the spot changed instantaneously through yellow to purple. This is the characteristic feature of such a compound as benzylamine type and it means that phenyl and amino radicals attach to the same carbon atom ${ }^{6}$, c) the ultraviolet spectrum had maximum absorption at $257 \mathrm{~m} \mu(\varepsilon, 220)$, indicating a typical benzene analogue substituted with alkyl groups, in which both amino and carboxyl radicals do not attach directly to benzene ring. The isom mers, having the molecular formula of $\mathrm{C}_{9} \mathrm{H}_{11} \mathrm{NO}_{2}$ and satisfying above three conditions, can be written in the three types as shown above, namely, $\beta$-phenyl- $\beta$-aminopropionic acid (I), $\alpha$ phenyl- $\alpha$-aminopropionic acid (II) and aminomethyl phenylacetic acid (III). Among these,

6) M. Sawai et al., J. Cbem. Soc. Japan, 76, 256 (1955). 


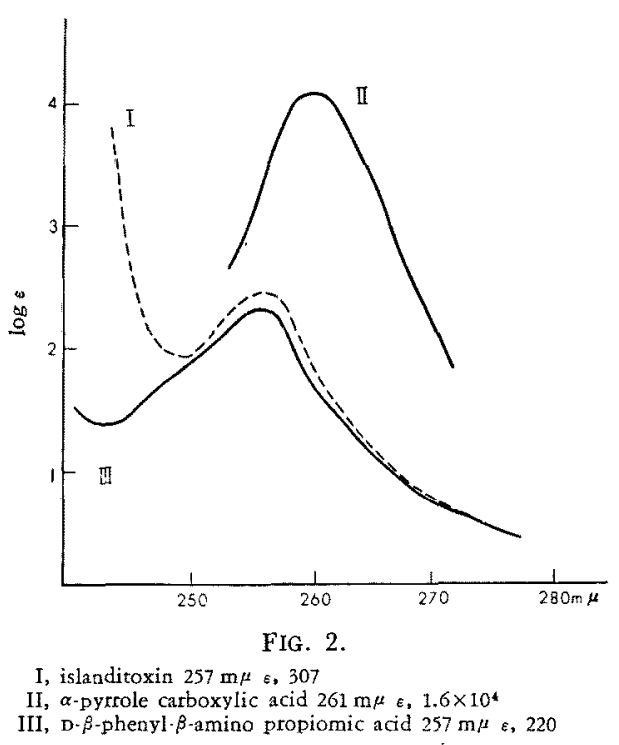

the isomer which has the possibility to change into cinnamic acid, is exclusively the $\beta$-phenyl$\beta$-aminopropionic acid. The fact that on the alkaline degradation $\mathrm{C}_{9} \mathrm{H}_{11} \mathrm{NO}_{2}$ as well as islanditoxin produced cinnamic acid supported formula (I) as the structure of this amino acid. There was prepared DL- $\beta$-phenyl- $\beta$-aminopropionic acid ${ }^{2}$ and solved into an optical antipode through the brucine salt of DL-formyl derivative $^{8)}$. The amino acid in the hydrolyzate was found to be identical with a synthetic $\mathrm{D}$-form by comparison of infrared spectra, chromatographic behavior and melting point. Moreover, measurement of the optical rotation of the amino acid showed $[\alpha]_{\mathrm{D}}^{25^{\circ}}=-9.6^{\circ}(c, 5.0$, in $1 \mathrm{~N}$ potassium hydroxide), which was in agreement with the value reported by Fisher ${ }^{83}$, hence (-) $\beta$-phenyl- $\beta$-aminopropionic acid in islanditoxin was proved to be of $\mathrm{D}$-series.

The remaining problem is to determine the chemical structure of the chlorine-containing amino acid.

As described above, $\alpha$-pyrrole carboxylic acid was obtained on the alkaline hydrolysis of islanditoxin. It is probable that $\alpha$-pyrrole carboxylic

7) Org. synth. Coll. vol. 3, 26.

8) E. Fisher, Bericbte, 44, 3166 (1911). acid was originated from the unidentified component, $\mathrm{C}_{5} \mathrm{H}_{5} \mathrm{NOCl}_{2}$ of the islanditoxin molecule.

As shown in Fig. 2, the ultraviolet absorption spectrum of islanditoxin corresponds to that of $\beta$-phenyl- $\beta$-aminopropionic acid. The $\varepsilon$ value of $\alpha$-pyrrole carboxylic acid is too large to consider that the acid is a component of islanditoxin. It is reasonable to assume that the origin of $\alpha$-pyrrole carboxylic acid in islanditoxin is dichloroproline, which had no absorption in ultraviolet region and is easily decomposed to $\alpha$-pyrrole carboxylic acid, liberating two moles of hydrogen chloride by alkali. Dehydrochloroislanditoxin (V), $\mathrm{C}_{24} \mathrm{H}_{29} \mathrm{O}_{7} \mathrm{~N}_{5} \cdot \mathrm{CH}_{3} \mathrm{OH}$, dehydrochloroislanditoxinic acid (VI), $\mathrm{C}_{24} \mathrm{H}_{31} \mathrm{O}_{8} \mathrm{~N}_{5}$. $\mathrm{H}_{2} \mathrm{O}$ and dehydrochloroislanditoxinic amide, $\mathrm{C}_{24} \mathrm{H}_{32} \mathrm{O}_{7} \mathrm{~N}_{6} \cdot \mathrm{H}_{2} \mathrm{O}$, all had strong absorption at $268 \mathrm{~m} \mu$ showing the formation of the pyrrole ring.

When islanditoxin was hydrogenated by $\mathrm{PtO}_{2}$ at $130^{\circ}$ for 8 hours at 180 atoms in ethanol solution and then decomposed by acid, proline was obtained in about 20\% yield in addition to the three kinds of amino acids, which was separated with celullose column chromatography. From the result of comparison of the quantitative data obtained chemically and biologically, it was concluded that the proline belongs to of L-series. It was reasonable to consider that Ldichloroproline in islanditoxin was dechlorinated through catalytic reduction to be converted to L-proline. The positions of chlorine atoms attached to pyrrolidine ring and the configuration concerned are yet undetermined and the investigation is now underway.

The next problem is to determine the amino acid sequence of the islanditoxin. Evidences that islanditoxin is a cyclic peptide are given as follows. a) In the infrared spectrum of islanditoxin there are shown no peaks corresponding to $-\mathrm{NH}^{+}$and $-\mathrm{COO}^{-}$. b) No DNP-islanditoxin is prepared by an ordinary method, showing the absence of free amino radicals. c) No C-terminal amino acid is obtained by hydrazinolysis of islanditoxin. d) By acetylation with acetic anhydride and pyridine the diacetyl is- 
landitoxin is prepared, which should be attributed to two hydroxyl groups of two moles of serine, comfirming no other acetylating function suth as $-\mathrm{NH}_{2}$ is absent. e) With steam distillation of islanditoxin hydrolyzate neither volatile acid nor amine are obtained. f) The molecular formula of islanditoxin is explained satisfactorily as a polypeptide consisting of five amino acid components. Consequently, islanditoxin is concluded to belong to a cyclic peptide.

The sequence of amino acid was established by partial hydrolysis. Preliminary experiments with enzymatic degradation using carbopeptidase and protease were unsuccessful. A search for the optimum condition for partial hydrolysis was first made by comparing the results of paper chromatography of the hydrolyzate and it was found that partial hydrolysis at room temperature using concentrated hydrochloric acid was the good condition.

The ninhydrin positive spot, $R_{F} 0.75$, after hydrolysis for 17 hours, was first detected. This spot was, on standing for further 6-13 days successively, divided into two spots, one of which was assigned to serine and the other to the further degradative peptide, $R_{F}$ 0.59. Now the first spot was termed peptide $A$ and the second termed peptide B. Peptides A and B were separated by a celullose column chromatography. The $\mathrm{N}$-terminal amino acids of peptides $\mathrm{A}$ and $\mathrm{B}$ were determined by DNP-method and their Cterminal amino acids by hydrazinolysis. As the results, peptides A and B were illustrated as follows showing that both have the same Nand C-terminal amino acids.

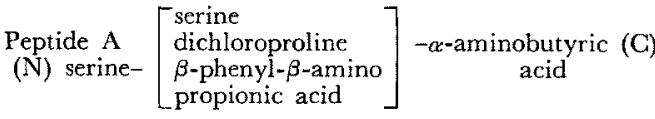

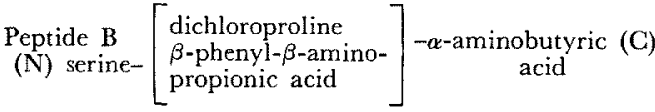

Combining the above two schemes and taking the cyclic peptide into account, islanditoxin should be written as below.

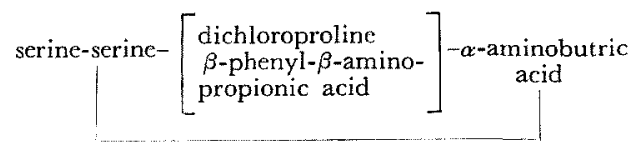

In the above scheme, the sequence of L-dichloroproline and $\mathrm{D}-\beta$-phenyl- $\beta$-aminopropionic acid is yet obscure and could not be determined by the acid hydrolysis, but could be by the following experiments.

Dehydrochloroislanditoxinic acid (VI), $\mathrm{C}_{24} \mathrm{H}_{31}$ $\mathrm{O}_{8} \mathrm{~N}_{5} \cdot \mathrm{H}_{2} \mathrm{O}$, U.V. $\max .268 \mathrm{~m} \mu \quad\left(\varepsilon, 1.2 \times 10^{4}\right)$, which was prepared under the limited condition of reacting exactly three moles of alkali to islanditoxin, was consisted of $\mathrm{L}$-serine as its $\mathrm{C}$ terminal amino acid, but $\mathrm{N}$-terminal amino group did not be detected by DNP-method. If the N-terminal amino acid of dehydrochloroislanditoxinic acid would be originally dichloroproline and converted to pyrrole ring by alkali, it was well understood that islanditoxin was changed to dehydrochloroislanditoxinic acid, by consuming three moles of $\mathrm{OH}^{-}$, liberating two moles of hydrogen chloride and splitting the peptide bond between pyrrole carboxylic acid and serine. To prove this assumption the dehydrochloroislanditoxinic acid (VI) was hydrogenated by $\mathrm{PtO}_{2}$ in glacial acetic acid. The hydrogenation of pyrrole ring was not proceed quantitatively under the conditions applied. The hydrogenated product (VII) was sensitive to ninhydrin and developed yellew colour. The product was also sensitive to isatine and developed intense blue, which is characteristic toward pyrrolidine and piperidine ${ }^{9}$. These data showed that the $\mathrm{N}$ terminal amino acid of (VII) was proline and that of (VI) was $\alpha$-pyrrole carboxylic acid.

On the basis of above degradation experiments, amino acid sequence was made clear and the structure of islanditoxin is proposed as L-seryl-L-seryl-L-dichloroprolyl - D - $\beta$ - phenyl $\beta$ aminopropionyl-L- $\alpha$-aminobutyric acid anhydride (VIII).

9) Traube et. al., Ber., 56, 1861 (1923) 


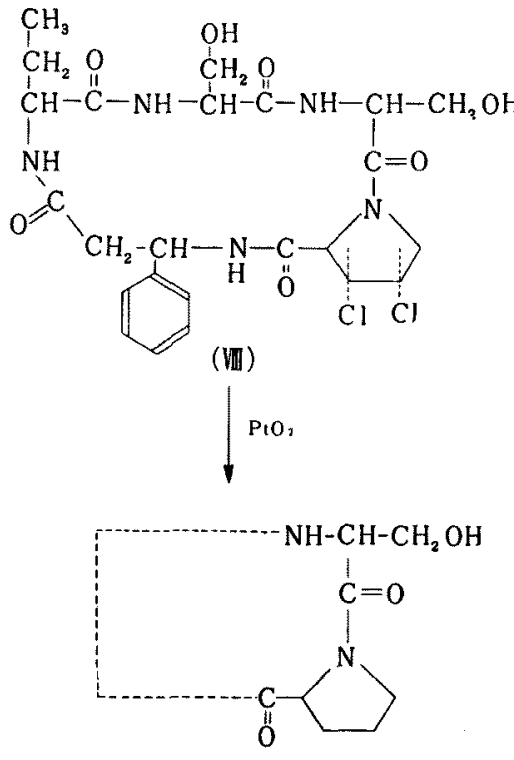

EXPERIMENTAL

\section{Paper Chromatography of Islanditoxin}

Toyo filter paper No. $51(30 \times 400 \mathrm{~mm})$ was used. The paper spotted with the sample was submitted to run about $30 \mathrm{~cm}$ long in the ascending method. The developed paper was dried well in an oven at $60^{\circ}$, and sprayed with N/10-alcohlic potassium hydroxide, After standing to dryness the paper was kept about 15 minutes in an atomosphers of chlorine gas formed by $1 \mathrm{~N}$-hydrochloric acid and potassium permanganate. A desiccator was used conveniently for this purpose. The paper was taken out from the desiccator and stood until completely free from chlorine gas. (It was needed about twenty minutes.) Then it was inserted into a freshly prepared mixture of equal volumes of $1 \%$ of benzidine in $10 \%$ acetic acid and $1 \%$ potassium iodide. The spot of peptide developed immediately blue colour. By Sanger et al. ${ }^{10}$, the solution of $1 \%$ iodine and $1 \%$ potassium iode and starch were used instead of above reagents. With islanditoxin preliminary treatment of papers with alkali was very effective fort he colouration. Solvent systems used and $R_{F}$ values was listed in Table $\mathrm{I}$.

10) F. Sanger and H. Tuppy, Biochem. $J ., 49,463$ (1951).

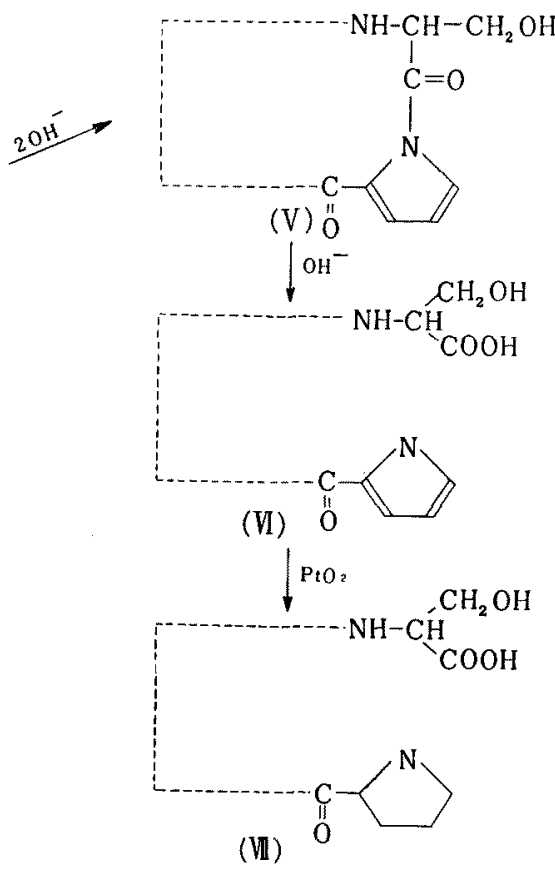

TABLE I.

Solvent Systems

methyl ethyl ketone: acetone: water

$(20: 2: 5)$

water saturated $n$-butyl alcohol

methyl isobutyl ketone: acetone:

methanol: water

$(30: 3: 10: 10)$

methyl isobutyl ketone: acetone: water

$(60: 18: 5)$

methyl isobutyl ketone: acetone: water $(5: 1: 15)$

chloroform : methanol : water

$(5: 1: 15)$

$$
\begin{array}{ll}
R_{F} \text { values } & \\
1.0 \\
0.84 \\
\\
0.71 \\
& 0.63 \\
& 0.19 \\
& 0
\end{array}
$$

Quantitative Analysis of $\alpha$-Aminobutyric Acid

The analysis was made according to the quite similar method for serine estimation ${ }^{4}$. The concentration of hydrochloric acid used was $6 \mathrm{~N} . \quad 0.86$ mole of $\alpha$-aminobutyric acid per one mole of islanditoxin was obtained on the hydrolysis for 20 hours.

\section{Isolation of $\alpha$-Pyrrole Carboxylic Acid and Cinnamic} Acid

Islanditoxin $(200 \mathrm{mg})$ was hydrolyzed at $130^{\circ}$ in a sealed pyrex tube with $20 \mathrm{ml}$ of saturated hot solution of barium hydroxide. After hydrolysis for 20 hours, 


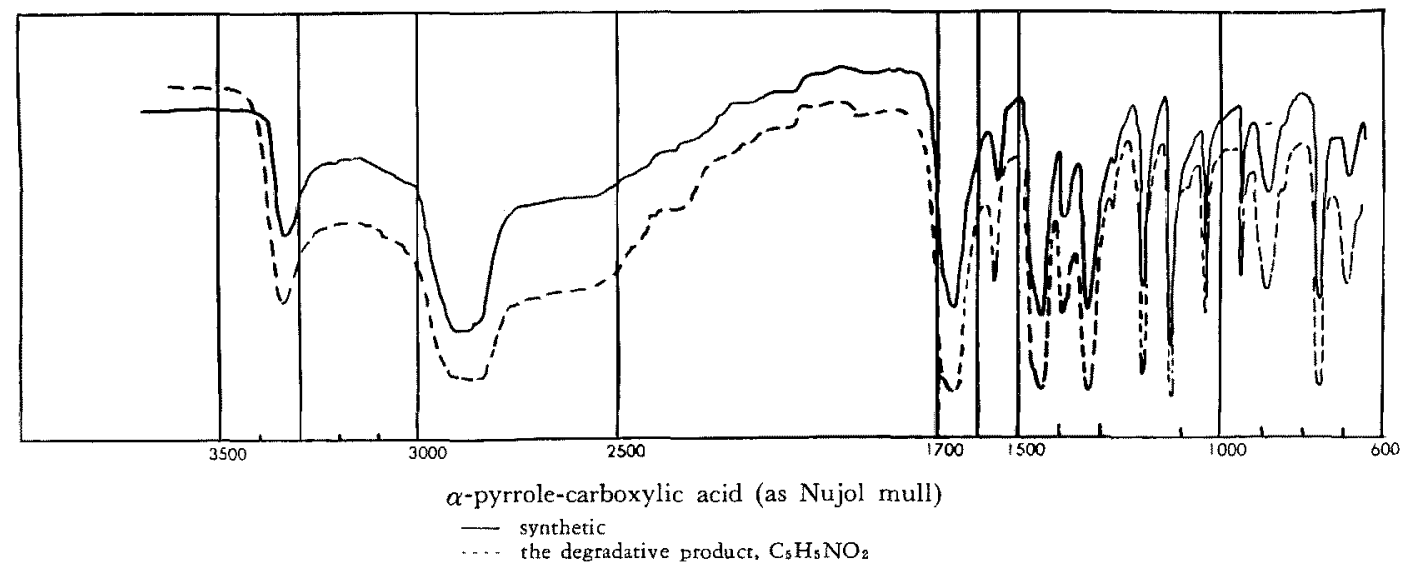

excess of barium hydroxide was removed from the solution as barium sulfate. The solution was acidified with sulfuric acid and shaken three times with equal volume of ethylacetate. After drying with sodium sulfate, the ethylacetate layer was evaporated to dryness and the residue was subjected to a celullose column chromatography ( $15 \mathrm{~mm} \times 200 \mathrm{~mm}$ ) using butyl alcohol saturated with $1.5 \mathrm{~N}-\mathrm{NH}_{4} \mathrm{OH}$ as a eluting solvent. The Whatman's ashless celullose powder was used. The eluate was collected with the aid of fraction collector in $3 \mathrm{ml}$ fraction each. Cinnamic acid was first eluted and $\alpha$ pyrrole carboxylic acid was later. The further purification was made by vacuum sublimation.

Cinnamic acid, subliming point $60^{\circ}$ in vacuo, m.p. $130^{\circ}$.

yield about $20 \mathrm{mg}$

Anal. Calcd. for $\mathrm{C}_{9} \mathrm{H}_{8} \mathrm{O}_{2}: \mathrm{C}, 72.96 ; \mathrm{H}, 5.44$. Found: C, 72.92; H, 5.47. $\alpha$-Pyrrole carboxylic acid, subliming at $70^{\circ}$ in vacuo, m.p. $180^{\circ}$ (decomp.). yield about $15 \mathrm{mg}$.

Anal. Calcd. for $\mathrm{C}_{3} \mathrm{H}_{5} \mathrm{NO}_{2}: \mathrm{C}, 54.05 ; \mathrm{H}, 4.51$; $\mathrm{N}, 12.61$. Found: $\mathrm{C}, 54.28 ; \mathrm{H}, 4.63 ; \mathrm{N}, 12.72$.

\section{Catalytic Reduction of Islanditoxin}

A solution of $200 \mathrm{mg}$ of islanditoxin in $20 \mathrm{ml}$ of ethylalcohol was hydrogenated over $50 \mathrm{mg}$ of $\mathrm{PtO}_{2}$ at 180 atoms. and $130^{\circ}$ for 8 hours. After removal of the catalyst by filteration, the solution was evaporated to dryness. The dichloroproline in islanditoxin was reduced about $20 \%$ as described later and the extinction of the band at $257 \mathrm{~m} \mu$ of the reaction mixture indicated that approximately three fourths of $\beta$-phenyl- $\beta$-amino-propionic acid was hydrogenated. The product, without further separation, was submitted to acid hydrolysis to get proline. The hydrolyzatc was subjected to a celullose column chromatography using butyl alcohol, acetic acid and water $(4: 1: 5)$ as a solvent system. Although proline did not obtained as the single component but was contaminated with a small amount of serine and $\alpha$-aminobutyric acid, the main fractions contained proline was collected and were used for optical determination of proline.

\section{Optical Determination of Proline}

First, total amount of proline in the sample was measured chemically by the method of F.B. Chivard ${ }^{11}$, which was the excellent method for quantitative determinntion of proline among the various amino acids. Next, L-proline content was estimated biologically using Leuc. mesenteroides. On the comparison of the two data together, proline obtained catalytic reduction of islanditoxin was found to belong to L-series.

Dehydrochloroislanditoxin (V) and Dehydrochloroislanditoxinic Acid (VI)

Islanditoxin (100 $\mathrm{mg})$ was dissolved in about $30 \mathrm{ml}$ of a mixture of acetone and methanol, and to this solution were added exactly 3 moles of N/10-sodium hydroxide. After standing a few hours, the crystal of dehydrochloroislanditoxin deposited was collected by filteration. yield $20 \mathrm{mg}$. U.V. $\max .268 \mathrm{~m} \mu$ ( $\varepsilon, 1.5 \times$ $10^{4}$ ). From the data of microanalyses, it was better to consider that $(\mathrm{V})$ took methanol rather than water as the solvent of crystallization, which was not lost by vacuum drying at $100^{\circ}$.

Anal. Calcd. for $\mathrm{C}_{24} \mathrm{H}_{29} \mathrm{O}_{7} \mathrm{~N}_{5}, \mathrm{CH}_{3} \mathrm{OH}: \mathrm{C}, 56.49$; $\mathrm{H}, 6.26$; N, 13.18. Found: C, 56.83 ; H, 6.18; $\mathrm{N}, 13.24$.

11) F.B. Chivard, J.B.C., 199, 91 (1952). 
The filterate was evaporated to dryness ( $\mathrm{pH}$ of solution was almost neutral) and then the residue was subjected to a celullose column chromatography using butyl alcohol saturated with $1.5 \mathrm{~N}-\mathrm{NH}_{4} \mathrm{OH}$ as a eluting solvent. Aliquot of cach eluted tube was tested with the indi- cator, brom phenol blue, and the fractions contained dehydrochloroislanditoxinic acid were collected. yield $40 \mathrm{mg}$.

Anal. Calcd. for $\mathrm{C}_{24} \mathrm{H}_{31} \mathrm{O}_{4} \mathrm{~N}_{5} \cdot \mathrm{H}_{2} \mathrm{O} ; \mathrm{C}, 53.82 ; \mathrm{H}$, $6.21 ; \mathrm{N}, 13.08$. Found: C, 53.75; H, 6.44; N, 12.95.
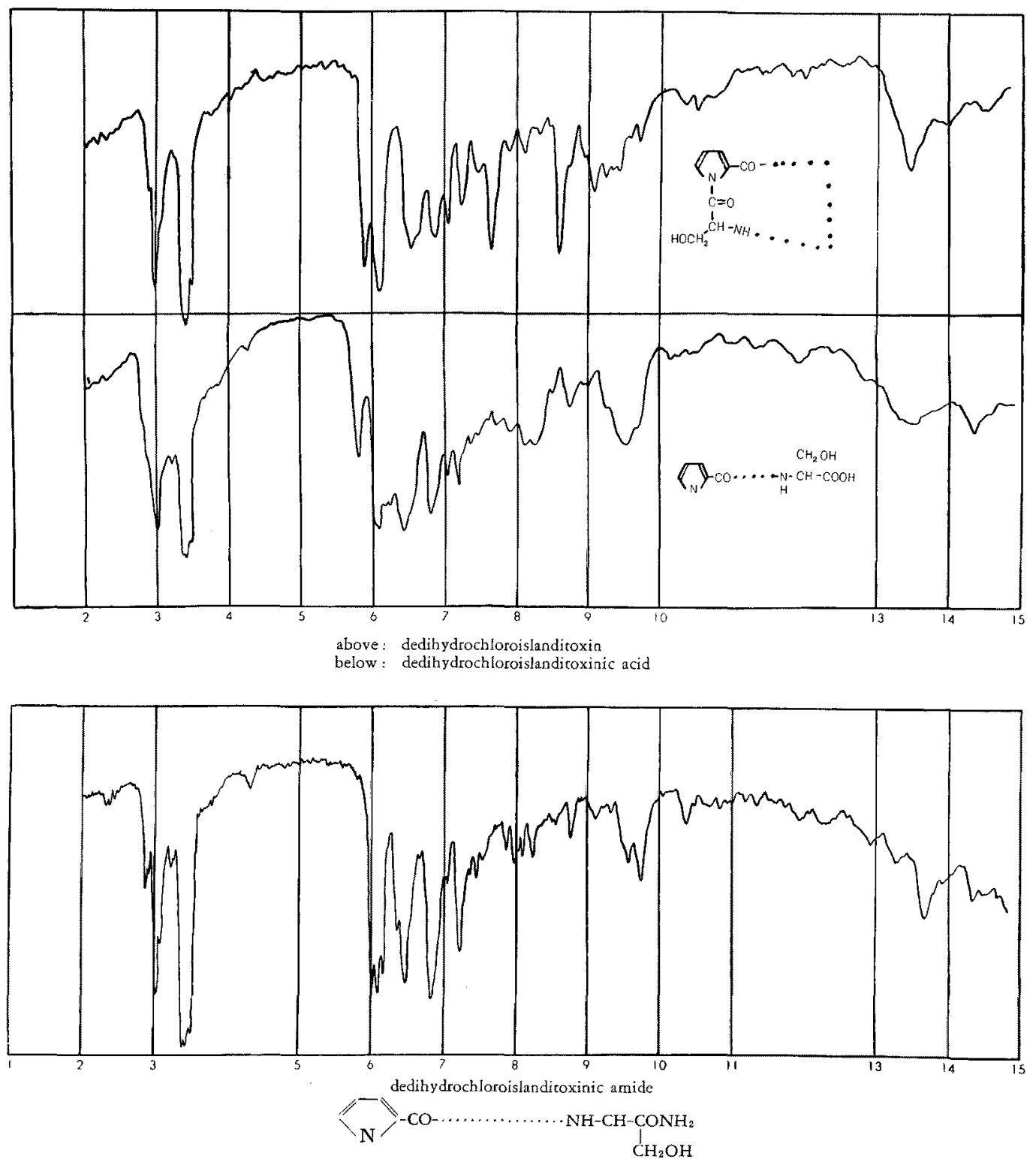


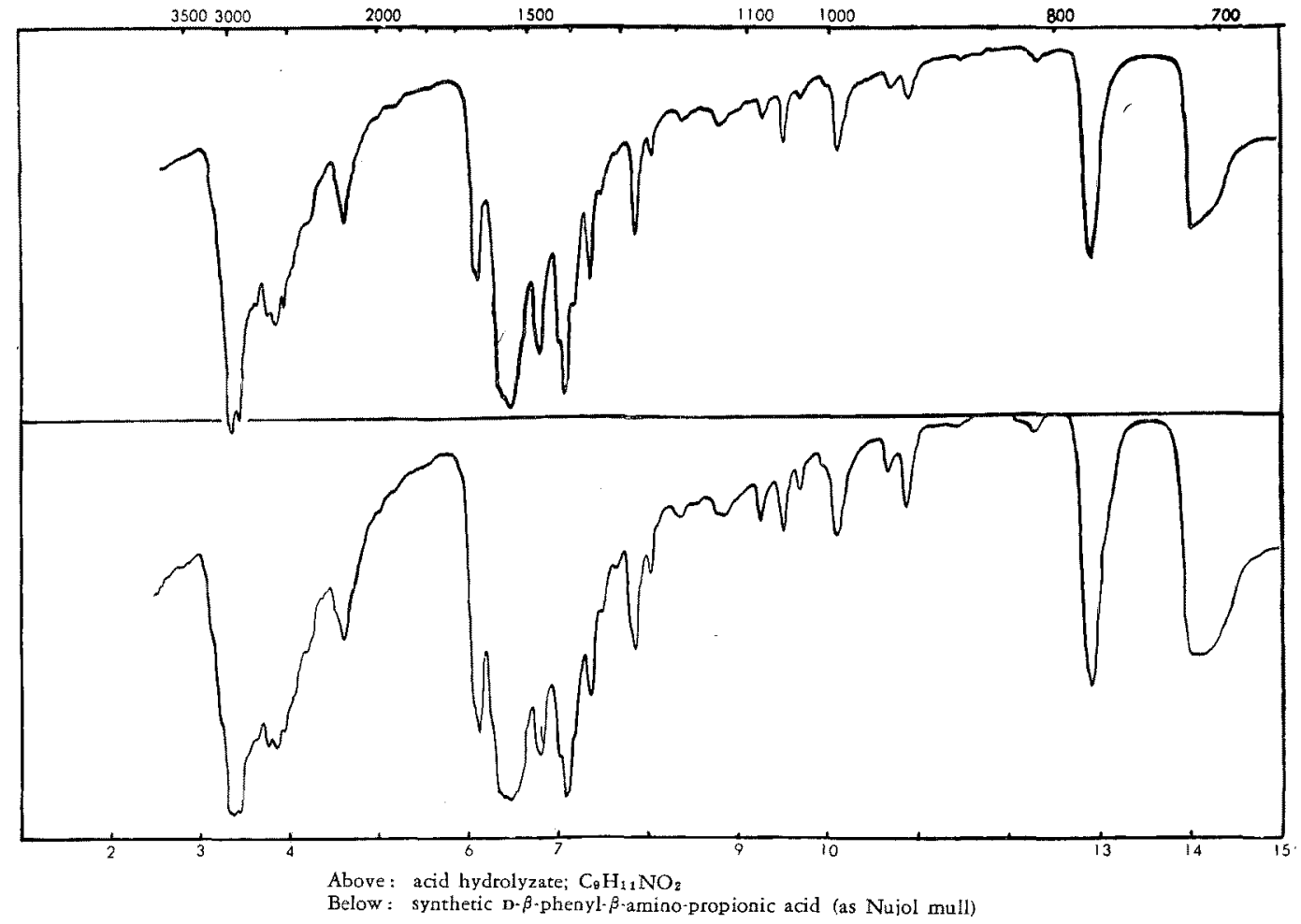

\section{Dehydrochloroislanditoxinic Amide}

After islanditoxin was added into excess liquid ammonia, the solution was kept at room temperature until ammonia was completely evaporated. The residue was washed with water repeatedly to remove ammonium chlolide, then with acetone and methanol successively and dried at $100^{\circ}$.

m.p. $268 \sim 73^{\circ}$ (docomp.) U.V. $\max .268 \operatorname{m} \mu(\varepsilon, 1.4 x$ $10^{4}$ )

Anal. Calcd. for $\mathrm{C}_{24} \mathrm{H}_{32} \mathrm{O}_{7} \mathrm{~N}_{6} \cdot \mathrm{H}_{2} \mathrm{O}: \quad \mathrm{C}, 53.92 ; \mathrm{H}$, $6.41 ; \mathrm{N}, 15.72$. Found: $\mathrm{C}, 54.13 ; \mathrm{H}, 6.94 ; \mathrm{N}$, 15.73 .

Quantitative estimation of amide in dehydrochloroislanditoxinic amide was carried out by the method of A.L. Levy et al. ${ }^{22}$. One mole of dehydrochloroislanditoxinic amide liberated 1.3 moles of ammonia in this procedure.

Hydrazinolysis of Peptide

Hydrazinolysis of islanditoxin, peptide $A$ and $B$ and dehydrochloroislanditoxinic acid were carried out ac-

12) A. L. Levy er a1., J. B. C., 213, 187 (1955). cording to the method of Akabori ${ }^{132}$. About $5 \mathrm{mg}$ of each of the samples was hydrazinolyzed with $1.5 \mathrm{ml}$ of anhydrous hydrazine at $100^{\circ}$ in a sealed tube for 10 hours. The reaction mixture was evaporated in vacuo over sulfuric acid to remove the excess hydrazine. To determine the terminal amino acid, the residue was dissolved in about $2.0 \mathrm{ml}$ of water and subjected to electrophoresis on Toyo filter paper No. 51 in lutidine acetate buffer at $\mathrm{pH} 6.2$ for three hours (20 volt per $\mathrm{cm}$ ). After electrophoresis, the paper was dried at $80^{\circ}$ and again chromatographed during 10 hours in an ascending method for the vertical direction against the moving

$\begin{array}{lcc}\quad \text { Sample } & \text { C-terminal amino acid } & R_{F} \text { value* } \\ \text { islanditoxin } & \text { none } & - \\ \text { peptide A } & \alpha \text {-aminobutyric acid } & 0.30 \\ \text { peptide B } & \alpha \text {-aminobutyric acid } & 0.30 \\ \text { Dehydrochloroislandi- } \quad \text { L-serine } & \\ \text { toxinic acid } & \\ \text { * As the development solvent, butyl alcohol : acetic acid : }\end{array}$

As the development solvent, butyl alcohol : acetic acid: water $(4: 1: 5)$ was used.

13) S. Akabori et al., Bull. Chem. Sor. Japan, 25, 214 (1952). 
line of the electrophoresis. The the paper was dried, developed with ninhydrin and $R_{F}$ value of free amino acid was identified. The above results were obtained.

Infrared Spectra of D- $\beta$-Phenyl- $\beta$-amino Propionic Acid (as Nujol mull)

The infrared spectrum of free amino acid was complicated in the ranges of $1600 \sim 1400 \mathrm{~cm}^{-1}$ on account of the bands $\mathrm{COO}^{-}$and benzene. And so, the presence of benzene was presumed from the spectrum of the hydrochloride of the amino acid ${ }^{4}$.

Acknowlegements The author wishes to express his sincere thanks to Prof. Y. Sumiki for his guidance throughout this work, to Dr. A.
Matsuyama and Dr. K. Miyao in his laboratory for their kind advices and supports to carry out this work. Grateful thanks are also due to Dr. H. Aida of the Institute of Applied Microbio$\operatorname{logy}$, University of Tokyo, for the biological estimation of L-proline, to Dr. K. Izaki in his faculty for the optical determination of $\alpha$ - aminobutyric acid.

The cost of this study was defrayed by the Ministry of Agriculture and Forestry, and of Japan Waksman Foundation, to whom author's thanks are due. 